\title{
PENGEMBANGAN DAN VALIDASI METODE UJI CADMIUM (Cd) PADA AIR PERMUKAAN SECARA SPEKTROMETRI SERAPAN ATOM NYALA
}

\section{Development and Validation of a Method for Cadmium (Cd) in Surface Water by Flame-Atomic Adsorption Spectrometry}

\author{
Chatimatun Nisa', Panji Saputra ${ }^{2}$, Evy Setiawati ${ }^{3}$ \\ 1,2,3 Balai Riset dan Standardisasi Industri Banjarbaru \\ Jl. Panglima Batur Barat No. 2 Banjarbaru Kalimantan Selatan \\ E-mail: evy.kemenperin@gmail.com
}

\begin{abstract}
Abstrak
Konsentrasi kadmium (Cd) pada air permukaan biasanya rendah dan secara langsung dapat mempengaruhi kualitas air. Penelitian ini bertujuan untuk mengembangkan metoda pengujian yang mempunyai limit deteksi lebih rendah dari SNI yang biasa digunakan sebagai standar metode pengujian pada air permukaan. Dalam menganalisis kandungan logam Cd dalam air permukaan, dapat digunakan metode Flame-Atomic Absorption Spectrophotometry (Flame-AAS). Penelitian ini merupakan pengembangan dari SNI 6989.16: 2009 tentang pengujian kadmium dalam air yang kisaran konsentrasinya ditetapkan 0,05-2,00 mg/L. Parameter validasi terdiri dari metode uji linieritas, akurasi, presisi, limit of detection (LoD), selektivitas, kekasaran, dan ketahanan. Kurva standar linier pada rentang konsentrasi $0,01-0,5 \mathrm{mg} / \mathrm{L}$ dengan nilai koefisien determinasi $(R$-square $) 0,9986$. Nilai Relative Standard Deviation (RSD) lebih rendah dari yang disyaratkan oleh RSD Horwitz. Persentase pemulihan sekitar 92-108\%. LoD yang diperoleh sebesar 0,003 $\mathrm{mg} / \mathrm{L}$ dengan nilai selektivitas, ketangguhan, dan ketahanan yang tinggi. Berdasarkan hasil tabulasi data statistik dan metode validasi, penelitian ini menunjukkan bahwa metode pengujian kadmium menggunakan Flame-Atomic Absorption Spectrophotometry (F-AAS) sesuai untuk digunakan sebagai metode pengujian standar pada air permukaan dengan kisaran konsentrasi 0,01-0,5 $\mathrm{mg} / \mathrm{L}$. Hasil penelitian ini dapat diajukan ke Badan Standardisasi Nasional sebagai bahan rekomendasi kaji ulang pengukuran $\mathrm{Cd}$ air permukaan pada konsentrasi rendah.
\end{abstract}

Kata kunci: Cadmium, validasi metode, air permukaan, konsentrasi rendah

\begin{abstract}
Cadmium (Cd) concentration on surface water is typically low and can directly influence the water quality. This study was aimed to develop a test method that has a lower detection limit than the SNI commonly used as a test standard for surface water, In analyzing the metal content of $C d$ in surface water, the F-AAS method can be used. This study developed SNI 6989.16:2009 about the testing of cadmium in water which concentration range is defined $0.05-2.00 \mathrm{mg} / \mathrm{L}$. Validation parameter consisted of linearity, accuracy, precision, LoD, selectivity, ruggedness and robustness test methods. The standard curve was linear over the concentration ranges of 0.01 $0.5 \mathrm{mg} / \mathrm{L}$ with the determination coefficient (R-square) values 0.9986 . The Relative Standard Deviation (RSD) value was lower than that required by RSD Horwitz. The recovery percentage was around 92-108\%. LoD obtained was $0.003 \mathrm{mg} / \mathrm{L}$ with high selectivity, ruggedness, and robustness values. The result showed that the Cadmium testing method using F-AAS was suitable to be used as standard testing methods in surface water with the concentration range of 0.01-0.5 $\mathrm{mg} / \mathrm{L}$. The results of this research can be submitted to the National Standardization Agency for recommendation to review of $\mathrm{Cd}$ measurements in the surface water at low concentrations.
\end{abstract}

Key words: Cadmium, method validation, surface water, low concentration

\section{PENDAHULUAN}

Logam berat di lingkungan akuatik telah mendapat perhatian yang cukup besar di seluruh dunia karena keberadaannya yang luas, kemampuan bertahan yang lama dan tingkat toksisitasnya terhadap lingkungan (Soliman et al., 2019; Yang et al., 2019). Logam berat umumnya didefinisikan sebagai logam dengan kerapatan, bobot atom, atau nomor atom yang relatif tinggi.

Asupan air yang terkontaminasi logam berat oleh manusia dan bentuk kehidupan lainnya dapat menyebabkan gangguan berbagai aktivitas metabolisme, yang menyebabkan gangguan kardiovaskular, neurologis, dan ginjal. Sebagian besar logam berat sangat beracun karena sebagai ion atau senyawa, logam berat larut dalam air dan dapat dengan mudah 
terakumulasi dalam jaringan tumbuhan atau hewan (Shah et al., 2020). Logam berat berbeda dari logam lain karena efek yang dihasilkan ketika terikat dengan organisme hidup. Logam berat mampu menggeser unsur-unsur yang bersifat vital sehingga menghalangi fungsi biologisnya. Saat ini tidaklah memungkinkan untuk hidup di lingkungan yang bebas logam berat (Tjahjono \& Suwarno, 2018).

Istilah "logam berat" dapat digantikan oleh istilah "logam yang berpotensi beracun" (Pourret \& Hursthouse, 2019). Akibat aktivitas manusia yang intensif dan perluasan industri serta produksi pertanian, sejumlah besar logam yang berpotensi beracun telah dibuang ke sungai di beberapa belahan dunia. Selain itu, residu logam yang berpotensi beracun di sungai yang terkontaminasi dapat terakumulasi dalam sedimen, (mikroorganisme, tumbuhan air, dan hewan). Hal ini berarti dalam ekosistem akuatik, logam berat yang terbawa oleh partikel halus menyebabkan penumpukan di sedimen. Kontaminasi logam berat dalam air dan sedimen telah menghasilkan dampak ekologi yang merugikan secara signifikan. Logam berat dilepaskan dari sedimen melalui proses suspensi ulang partikulat dan aktivitas mikro-organisme di dalam sedimen dan antar muka antara sedimenair. Bentuk logam berat yang dapat larut ini dapat ditemukan pada krustasea, jenis ikan bersirip dan kerang serta dapat berpindah ke manusia melalui jalur rantai makanan (Yi et al., 2011). Di antara sumber polutan, logam menjadi perhatian khusus karena kemungkinan efek toksiknya dan kemampuannya untuk mengalami bioakumulasi dalam ekosistem air (Censi et al., 2006). Oleh karena itu perlu dilakukan evaluasi terhadap konsentrasi logam berat dalam air.

Salah satu cara untuk mengukur kadar logam berat di air adalah dengan menggunakan metode Standar Nasional Indonesia. Apabila laboratorium ingin mengembangkan metode, maka metode tersebut harus divalidasi. Validasi metode dilakukan untuk menjamin bahwa metode analisis bersifat reprodusibel, spesifik, dan akurat serta tahan pada kisaran analit yang akan dianalisis.Saat ini proses validasi metode telah diintensifkan untuk mencapai tingkatan kualitas yang lebih tinggi (Araujo, 2009). Penelitian ini bertujuan untuk mengevaluasi kesesuaian metode dengan studi laboratorium sebagai standar metode pengujian pada air permukaan. Proses ini bertujuan untuk mengkonfirmasi bahwa metode yang diterapkan telah sesuai. Metode yang dibuat dan/atau dikembangkan oleh laboratorium, metode standar yang digunakan di luar cakupan, dan modifikasi dari metode standar harus divalidasi oleh laboratorium. Pengujian kadar logam terlarut pada air permukaan seperti Cd dapat dilakukan menggunakan peralatan yang lebih teliti seperti AAS jenis tungku karbon (graphite fumace) atau AAS Flameless, atau ICP-MS.

\section{TINJAUAN PUSTAKA}

Berdasarkan penelitian sebelumnya yang dilakukan di perairan Moro Demak (terletak di sebelah timur Pelabuhan Tanjung Emas Semarang) kandungan Cd pada permukaan air mencapai $0,116 \mathrm{mg} / \mathrm{L}$ (Tjahjono \& Suwarno, 2018). Di sisi lain, konsentrasi Cd dalam sampel air permukaan memungkinkan mempunyai kadar sangat rendah ( $\leq 0.001 \mathrm{mg} / \mathrm{L})$. Selain itu, konsentrasi $\mathrm{Cd}$ yang sangat rendah juga terdeteksi dalam sampel air Sungai Buriganga, Turag dan Shitalakha, Bangladesh (Ahmad et al., 2010; Islam et al., 2014; Arefin et al., 2016). Meskipun mempunyai kadar rendah, logam Cd berpotensi merugikan makhluk hidup karena bersifat racun. Pada kelarutan $\mathrm{Cd}$ dalam konsentrasi tertentu, mampu membunuh biota perairan. Seperti contohnya, apabila kelarutan Cd sebesar 0,0028-4,6 mg/L akan menyebabkan kematian biota perairan yang tergolong famili oligochaeta dalam kurun waktu 24 hingga 96 jam; apabila kelarutan Cd sebesar 0,005-0,15 $\mathrm{mg} / \mathrm{L}$ akan menyebabkan kematian biota perairan yang tergolong famili crustacea dalam kurun waktu 24 hingga 504 jam; apabila kelarutan Cd sebesar 0,003-18,00 mg/L akan menyebabkan kematian biota perairan yang tergolong famili insecta dalam kurun waktu 24 hingga 672 jam (Roza \& Muhelni, 2019). Hal ini menandakan bahwa logam $\mathrm{Cd}$ berpotensi racun terhadap makhluk hidup meskipun dalam konsentrasi yang rendah. Oleh karena itu, baku mutu kadar Cd berdasarkan Peraturan Pemerintah RI No. 82 tahun 2001 tentang Pengelolaan Kualitas Air dan Pengendalian Pencemaran Air adalah maksimal sebesar 0,01 $\mathrm{mg} / \mathrm{L} \quad$ (Republik Indonesia, 2001) dan berdasarkan Peraturan Gubernur Kalimantan Selatan No. 05 tahun 2007 tentang Peruntukan \& Baku Mutu Air Sungai, maksimal kadar Cd yang diperbolehkan adalah sebesar $0,1 \mathrm{mg} / \mathrm{L}$ (Pemerintah Provinsi Kalimantan Selatan, 2007).

Di Indonesia, pengukuran Cd pada air mengacu pada metode SNI 6989.16:2009 (Badan Standarisasi Nasional, 2009). Pengukuran Cd pada konsentrasi rendah $(0,01$ $0,5 \mathrm{mg} / \mathrm{L})$ saat ini belum diakomodir dalam SNI 6989.16:2009. Metode SNI tersebut digunakan untuk penentuan logam kadmium (Cd) dalam air dan air limbah secara SSA - nyala pada kisaran kadar Cd cukup tinggi, yaitu 0,05 mg/L sampai dengan 2,0 $\mathrm{mg} / \mathrm{L}$ dan panjang gelombang 228,8 $\mathrm{nm}$. 
Validasi metoda analisis merupakan percobaan di laboratorium untuk menilai parameter tertentu, berdasarkan data-data sehingga terbukti bahwa parameter tersebut memenuhi persyaratan untuk penggunaannya. Beberapa validasi dari metode analisis yang harus dapat diuraikan. Prosedur validasi metode meliputi presisi, akurasi, selektivitas, linearitas, limit deteksi, ketangguhan metode (ruggedness), dan kekuatan (robustness) (Ravisankar et al., 2015). Apabila unsur-unsur tersebut dapat dipertanggungjawabkan maka suatu metode analisis tersebut dapat dikatakan valid sehingga dapat digunakan dalam analisis rutin. Validasi metode analisis terdiri dari (Harmita, 2004):

1. Linearitas. Linearitas menunjukkan kemampuan suatu metode analisis untuk memperoleh hasil pengujian yang sesuai dengan konsentrasi analit yang terdapat pada sampel pada kisaran konsentrasi tertentu.

2. Presisi. Presisi merupakan ukuran yang menunjukkan derajat kesesuaian antara hasil uji individu sampel, yang diukur melalui penyebaran hasil individu sampel dari ratarata pengulangan sampel dari campuran yang homogen.

3. Akurasi. Akurasi merupakan persen perolehan kembali (recovery) analit yang ditambahkan. Dalam rangka mencapai akurasi yang tinggi, dapat dilakukan dengan menurunkan galat sistematik dengan cara melakukan pengujian sesuai prosedur, pengujian secara cermat, pengontrolan suhu, peralatan yang telah dikalibrasi, dan sebagainya. Akurasi menunjukkan ukuran kadar analit yang sebenarnya dengan kedekatan hasil analisis (Iskandar et al., 2017)

4. Limit deteksi. Merupakan jumlah terkecil analit di dalam sampel yang dapat terdeteksi dan masih menghasilkan respon signifikan dibanding dengan blanko.

5. Selektivitas. Merupakan kemampuan yang hanya mengukur zat tertentu saja secara teliti dengan adanya komponen lain yang mungkin ada dalam matriks contoh uji.

6. Ketahanan. Untuk memvalidasi ketahanan suatu metode perlu dibuat perubahan metodologi yang kecil dan terus menerus dan mengevaluasi respon analitik dan efek presisi dan akurasi.

7. Ketangguhan. Ketangguhan menunjukkan tidak adanya pengaruh perbedaan hasil uji terhadap operasi atau lingkungan kerja. Ketangguhan merupakan ukuran ketertiruan kondisi operasi normal antar analis dan antara laboratorium. Ketangguhan dapat diuji untuk mengetahui adanya kesalahan nonlinier dengan cara uji t-s student (Burns et al., 2009).

\section{METODE PENELITIAN}

\section{Alat}

Flame Atomic Absorption Spectrofotometry, Lampu Katoda berongga (Hollow Cathode Lamp/HCL) Cadmium, pemanas listrik, seperangkat alat saring vakum, saringan membrane dengan ukuran pori $0,45 \mu \mathrm{m}$

\section{Bahan}

Larutan baku induk Cd 1000 mg/L (Merck), aquabidest dan sampel air permukaan.

\section{Penyiapan Larutan Baku Kerja}

Larutan baku 1000 ppm untuk logam Cd diencerkan hingga diperoleh deret konsentrasi logam Cd sebesar 0,01; 0,05; 0,10; 0,2; dan 0,5 $\mathrm{mg} / \mathrm{L}$.

\section{Liniearitas}

Uji linieritas dilakukan dengan metode pengukuran kurva kalibrasi yang diperoleh dengan menghubungkan antara konsentrasi dengan absorbansi terukur. Sebagai parameter adanya hubungan linier digunakan koefisien kolerasi ( $r$ ) dan koefisen variansi fungsi regresi pada analisis regresi linier $y=b x+a$. Kurva kalibrasi dibuat dengan menghubungkan antara konsentrasi dengan serapan dari larutan baku logam Cd konsentrasi 0,01; 0,05; 0,10; 0,2; dan $0,5 \mathrm{mg} / \mathrm{L}$. Batas penerimaan linieritas adalah minimal \%R $=99.7 \%$ (Chan et al., 2004).

\section{Uji Presisi dan Akurasi}

Presisi diukur dengan mengulang pengukuran sampel air permukaan sebanyak 10 (sepuluh) kali ulangan, kemudian dihitung nilai RSD pengulangan untuk kemudian dibandingkan dengan nilai RSD dengan nilai Horwitz (Sukaryono et al., 2017). Nilai \% RSD yang diperoleh dari hasil pengulangan pengujian tidak diperkenankan melebihi $2 / 3$ batasan presisi yang dirumuskan oleh persamaan Dr. William Horwitz (Horwitz \& Albert, 1995). Akurasi dilakukan dengan menguji sampel air permukaan yang sudah diketahui konsentrasinya, lalu ditambahkan larutan standar (spike) sesuai kadar target value yang dihasilkan. Pereaksi masing-masing parameter ditambahkan, lalu dihitung \% recovery (temu balik). Batas keberterimaan \% temu balik adalah sebesar $100 \pm 10 \%$ (Sumardi, 2002). 


\section{Limit Deteksi}

Pada pengukuran limit deteksi, sampel blanko atau sampel blanko yang dispike diukur dengan konsentrasi kecil yang masih bisa dibaca alat, dengan 10 (sepuluh) kali ulangan. Kurva kalibrasi dibuat dari sederetan larutan sampel tersebut dan diukur nilai serapannya, kemudian dihitung nilai standar deviasinya, kemudian dhitung pula batas deteksi metode (MDL), yaitu 3 kali standar deviasi (Purwanto et al., 2007).

\section{Selektivitas}

Sampel dengan konsentrasi tertentu dibandingkan dengan sampel dengan konsentrasi yang sama dengan sampel konsentrasi tertentu tetapi dengan penambahan penggangu. Dilakukan pengulangan pengukuran konsentrasi sampel sebanyak 6 (enam) kali. Apabila t-hit < t-tab, maka selektivitas dianggap memenuhi syarat (Pratama et al., 2016).

\section{Ketahanan}

Deret larutan standar $(0,01 ; 0,05 ; 0,10 ; 0,2$; dan $0,5 \mathrm{mg} / \mathrm{L}$ ) dibuat dengan 3 (tiga) kali ulangan pada waktu yang berbeda-beda. Data pengulangan tersebut kemudian diolah dengan Anova dan dibandingkan nilai $F$ hitung (F-hit) dan F tabel (F-tab). Apabila F-hit < Ftab maka ketahanan dinilai memenuhi syarat.

\section{Ketangguhan}

Uji ketangguhan dilakukan dengan cara membandingkan hasil pengukuran pada 2 (dua) analis yang berbeda pada waktu yang sama, minimal dilakukan 3 (tiga) kali ulangan waktu. Hasil pengulangan ini diolah melalui SPSS dengan t-test : Paired Two Sample for Means sehingga diperoleh nilai $\mathrm{T}$ hitung (t-hit) dan $\mathrm{T}$ tabel (t-tab). Apabila t-hit $<\mathrm{t}$-tab maka ketangguhan memenuhi syarat.

\section{HASIL DAN PEMBAHASAN}

Pada penelitian ini, penentuan validasi metode uji kadmium (Cd) pada air permukaan menggunakan AAS flame dengan memperhatikan beberapa parameter antara lain kondisi optimum analisis. Kondisi optimum analisis diperoleh dengan mengamati serapan yang optimum pada panjang gelombang maksimum unsur kadmium (Cd) pada setiap perubahan arus lampu, lebar celah, laju alir contoh, laju alir asetilen, laju alir udara, dan tinggi pembakar seperti disajikan pada Tabel 1 sebagai berikut :

Tabel 1. Kondisi optimum AAS

\begin{tabular}{llc} 
No & \multicolumn{1}{c}{ Parameter } & Cd \\
\hline 1. & Panjang gelombang, $\mathrm{nm}$ & 228,8 \\
2. & Arus lampu, $\mathrm{mA}$ & 3 \\
3. & Lebar celah, $\mathrm{nm}$ & 0,5 \\
4. & Laju alir asetilen, I/menit & 1,4 \\
5. & Laju alir udara, I/menit & 10 \\
6. & Laju alir contoh, ml/menit & 4,5 \\
7. & Tinggi pembakar, mm & 12 \\
\hline
\end{tabular}

\section{Kurva kalibrasi}

Linearitas merupakan ukuran seberapa baik plot kalibrasi respons terhadap konsentrasi mendekati garis lurus. Linearitas dapat dinilai dengan melakukan pengukuran tunggal pada beberapa analit konsentrasi. Data tersebut kemudian diolah menggunakan regresi linear kuadrat terkecil. Kemiringan plot yang dihasilkan, intersep dan koefisien korelasi memberikan informasi yang diinginkan tentang linearitas (Ravisankar et al., 2015). Idealnya, hubungan linier diperoleh apabila jika nilai slope $=0$ dan $r=$ +1 atau -1 bergantung pada arah garis. Nilai intersep menandakan tingkat kepekaan analisis, utamanya instrumen yang digunakan (Harmita, 2004).

Linearitas dilakukan dengan menghubungkan respon antara 5 (lima) deret konsentrasi larutan standar logam $\mathrm{Cd}$ dengan nilai absorbansi yang terukur pada instrumen. Parameter korelasi ( $r$ ) dan koefisien fungsi regresi didapatkan dari kurva kalibrasi (Tabel 2, Gambar 1).

Tabel 2. Absorbansi deret standar Cd

\begin{tabular}{ccc}
\hline No. & Konsentrasi $\mathbf{~} \mathbf{g} / \mathbf{L} \mathbf{~ ( x )}$ & Absorbansi $(\mathbf{Y})$ \\
\hline 1 & 0,010 & 0,0000 \\
2 & 0,050 & 0,0220 \\
3 & 0,100 & 0,0422 \\
4 & 0,200 & 0,0841 \\
5 & 0,500 & 0,2070 \\
\hline & Slope & $=0,3857$ \\
& Intersep & $=0,0045$ \\
& $\mathrm{R}^{2}$ & $=0,9986$
\end{tabular}




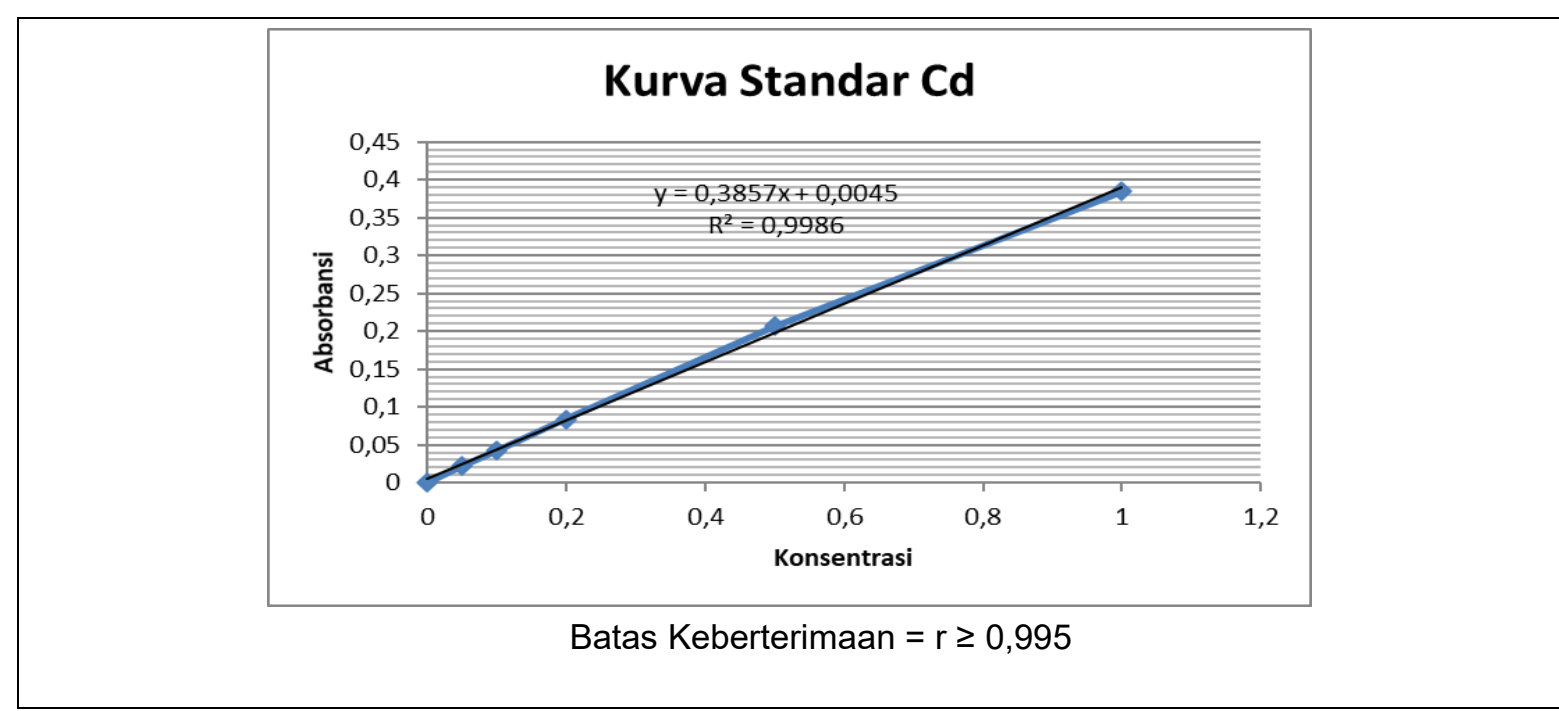

Gambar 1. Kurva standar logam Cd

Hubungan linier antara konsentrasi terhadap absorbansi memiliki persamaan garis y $=0,3857 x+0,0045$. Berdasarkan Gambar 1, batas keberterimaan validasi linearitas pada penelitian ini mempunyai nilai koefisien korelasi (r) yaitu > 0,995, sehingga dapat disimpulkan bahwa kurva kalibrasi logam $\mathrm{Cd}$ yang dibuat telah linear.

\section{Uji Presisi dan Akurasi}

Presisi menunjukkan tingkat kedekatan (derajat sebar) antara serangkaian pengukuran yang diperoleh dari beberapa sampling yang sama untuk sampel homogen dalam kondisi yang ditentukan. Presisi diukur dengan mengukur nilai deviasi standar relatif (RSD) dari satu set data. Penilaian dilakukan dengan menentukan RSD. Pengulangan dievaluasi dengan mengukur 10 larutan sampel. Nilai RSD yang diperoleh untuk \% uji pengulangan adalah 2,71, sedangkan \% nilai Horwitz adalah 7,93 (Tabel 3a). Oleh karena itu, dapat dikatakan demikian metode F-AAS menunjukkan presisi yang baik berdasarkan RSD nilai yang diperoleh.

Tabel 3. Uji presisi (a) dan uji akurasi (b)

\begin{tabular}{|c|c|c|c|c|c|}
\hline Ulangan & Hasil Uji (mg/L) & Konsentrasi & Spike & Spike + & Recovery (\%) \\
\hline 1 & 0,048 & (mg/L) & $(\mathrm{mg} / \mathrm{L})$ & $(\mathbf{m g} / \mathrm{L})$ & \\
\hline 2 & 0,050 & 0.025 & 0,025 & 0,052 & 108,00 \\
\hline 3 & 0,049 & & & & \\
\hline 4 & 0,050 & 0,025 & 0,025 & 0,052 & 108,00 \\
\hline 5 & 0,050 & 0,025 & 0,025 & 0,051 & 104,00 \\
\hline 6 & 0,048 & 0,025 & 0,025 & 0,051 & 104,00 \\
\hline 7 & 0,048 & & & & \\
\hline 8 & 0,048 & 0,025 & 0,025 & 0,052 & 108,00 \\
\hline 9 & 0,050 & 0,025 & 0,025 & 0,049 & 96,00 \\
\hline 10 & 0,052 & 0,025 & 0,025 & 0,049 & 96,00 \\
\hline Rerata & 0,0493 & 0025 & 0.025 & 0.048 & 92.00 \\
\hline SD & 0,0013 & & & & \\
\hline RSD & 2,7130 & 0,025 & 0,025 & 0,048 & 92,00 \\
\hline Tabel Horwitz & 7,93 & 0,025 & 0,025 & 0,050 & 100,00 \\
\hline
\end{tabular}

(a) Uji presisi

(b) Uji akurasi

Akurasi adalah merupakan metode pengukuran kedekatan nilai terukur antara nilai yang sebenarnya dengan hasil analisis. Pengujian akurasi dilakukan dengan perhitungan persentase temu balik (recovery). Penentuan temu balik dilakukan dengan spiking teknik. Konsentrasi larutan standar yang diketahui (0,025 $\mathrm{mg} / \mathrm{L})$ ditambahkan pada sampel air 
permukaan konsentrasi 0,025 $\mathrm{mg} / \mathrm{L}$. Sampel diukur, dihitung dan dibandingkan dengan yang diketahui nilai standar yang ditambahkan. Nilai recovery untuk akurasi ditunjukkan pada Tabel $3 \mathrm{~b}$, dengan persentase recovery antara 90$110 \%$, sesuai yang dipersyaratkan oleh SNI 6989.16:2009, yaitu pada kisaran $85 \%$ sampai dengan $115 \%$. Oleh karena itu, metode yang dikembangkan telah dinilai akurat untuk penghitungan $\mathrm{Cd}$.

\section{Limit Deteksi}

Limit deteksi bertujuan untuk menghindari penulisan sertifikat hasil uji yang tidak informastif karena tidak terdeteksi (not detectable, ND). Salah satu tekniknya adalah menggunakan penentuan limit deteksi metode (method detection level, MDL). MDL mengukur kemampuan laboratorium dalam menerapkan pengujian pada kadar rendah metode tersebut (Hadi, 2010). MDL didefinisikan sebagai konsentrasi terukur minimum dari suatu zat yang dapat dinyatakan dengan keyakinan 99\% bahwa konsentrasi yang diukur dapat dibedakan dari hasil metode blangko (US Environmental Protection Agency, 2016).

Tabel 4. Pengukuran MDL

\begin{tabular}{|c|c|c|c|c|c|}
\hline $\mathbf{n}$ & $\mathrm{X}$, teoritis & $\mathbf{Y}$ & $\mathrm{X}$, terbaca & X, terhitung & satuan \\
\hline 1 & 0,05 & 0,0199 & 0,050 & 0,041 & ppm \\
\hline 2 & 0,05 & 0,0207 & 0,052 & 0,043 & ppm \\
\hline 3 & 0,05 & 0,0197 & 0,049 & 0,041 & $\mathrm{ppm}$ \\
\hline 4 & 0,05 & 0,0203 & 0,051 & 0,042 & ppm \\
\hline 5 & 0,05 & 0,0196 & 0,049 & 0,041 & ppm \\
\hline 6 & 0,05 & 0,0203 & 0,051 & 0,042 & ppm \\
\hline 7 & 0,05 & 0,0201 & 0,050 & 0,042 & ppm \\
\hline 8 & 0,05 & 0,0208 & 0,052 & 0,044 & ppm \\
\hline 9 & 0,05 & 0,0206 & 0,052 & 0,043 & ppm \\
\hline \multirow[t]{4}{*}{10} & 0,05 & 0,0207 & 0,052 & 0,043 & ppm \\
\hline & & & rerata & 0,042 & ppm \\
\hline & & & SD & 0,001 & $\mathrm{ppm}$ \\
\hline & & & $M D L=3 * S D$ & 0,003 & ppm \\
\hline
\end{tabular}

MDL dihasilkan dari mengukur absorbansi 10 buah larutan spike, dihitung konsentrasi unsur dan standar deviasinya. MDL adalah 3 kali standar deviasi. Pengukuran MDL ditunjukkan pada Tabel 4. Pada studi ini didapatkan MDL sebesar 0,003 $\mathrm{mg} / \mathrm{L}$.

\section{Selektivitas}

Selektivitas metode mengacu pada sejauh mana sampel dapat menentukan analit tertentu dalam kompleks campuran (matriks sampel) tanpa gangguan dari komponen lain dalam campuran. Selektivitas juga disebut sebagai degree of bias (derajat penyimpangan) dari hasil analisis terhadap sampel yang mengandung bahan yang ditambahkan berupa senyawa asing, senyawa sejenis atau cemaran dan dibandingkan dengan sampel yang tidak mengandung tambahan senyawa. Jika respon dapat dibedakan dari semua respon lainnya, metodenya dikatakan selektif (Harmita, 2004).

Tabel 5. Selektivitas pengukuran Cd

\begin{tabular}{ccc}
\hline Pengulangan & Kadar sampel & $\begin{array}{c}\text { Kadar sampel yang diganggu 1 } \\
\text { ppm Zn }\end{array}$ \\
\hline 1 & 0,100 & 0,100 \\
2 & 0,102 & 0,103 \\
3 & 0,103 & 0,103 \\
4 & 0,103 & 0,103 \\
5 & 0,102 & 0,101 \\
6 & 0,105 & 0,100 \\
\hline Test: Paired Two Sample & & Variable 2 \\
for Means & & Variable 1
\end{tabular}




\begin{tabular}{lrr}
\hline Pengulangan & Kadar sampel & \multicolumn{2}{c}{ Kadar sampel yang diganggu 1 } \\
$\mathrm{ppm} \mathrm{Zn}$
\end{tabular}

Untuk menentukan apakah rata-rata respon pengujian sampel digangggu secara statistik tidak berbeda dari rata-rata respon sampel tidak diganggu, satu arah analisis varians atau uji-t berpasangan (paired t-test) sampel dilakukan. Berdasarkan uji selektifitas dapat dinyatakan bahwa metode analisis dinyatakan selektif, ditunjukkan dengan t-hit $<\mathrm{t}$ tab (Tabel 5).

\section{Ketangguhan dan Ketahanan}

Ketahanan merupakan ukuran dari kemampuan metode uji untuk tak terpengaruh dengan sejumlah kecil variasi dan perubahan berbagai parameter pada metode uji sehingga mampu menghasilkan performa yang tetap baik seperti pada kondisi biasanya (Sukaryono et al., 2017).

Tabel 6. Ketahanan pengukuran $\mathrm{Cd}$

\begin{tabular}{cccc}
\hline \multirow{2}{*}{ Konsentrasi } & \multicolumn{3}{c}{ Pengulangan } \\
\cline { 2 - 4 } & $\mathbf{1}$ & $\mathbf{2}$ & $\mathbf{3}$ \\
\hline 0,010 & 0,0095 & 0,0081 & 0,0083 \\
0,050 & 0,0307 & 0,0303 & 0,0275 \\
0,100 & 0,0594 & 0,0554 & 0,0543 \\
0,200 & 0,1213 & 0,1156 & 0,1180 \\
0,500 & 0,2729 & 0,2631 & 0,2731 \\
\hline
\end{tabular}

Anova: Single Factor

SUMMARY

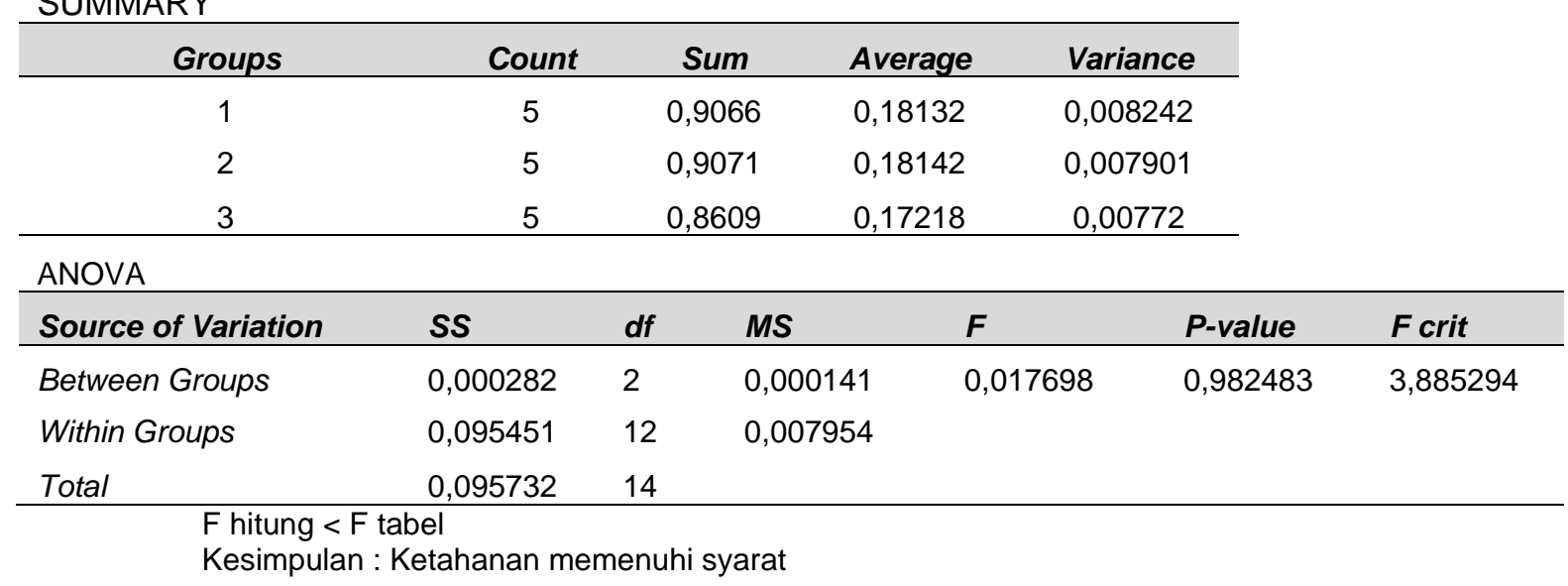


Ketahanan, yang merupakan uji intralaboratorium, pada umumnya diuji berdasarkan uji f-student (Burns et al., 2009). Berdasarkan uji ketahanan dapat dinyatakan bahwa ketahanan metode analisis Cd memenuhi persyaratan, ditunjukkan dengan f-hit $<$ f-tab (Tabel 6).

Tabel 7. Ketangguhan pengukuran $\mathrm{Cd}$

\begin{tabular}{|c|c|c|c|}
\hline \multirow{2}{*}{ Analis } & \multicolumn{3}{|c|}{ Waktu } \\
\hline & 1 & 2 & 3 \\
\hline 1 & 0,494 & 0,495 & 0,492 \\
\hline \multirow[t]{2}{*}{2} & 0,484 & 0,494 & 0,479 \\
\hline & & Variable 1 & Variable 2 \\
\hline Mean & & 0,493666667 & 0,485666667 \\
\hline Variance & & 0,000002333 & 0,000005833 \\
\hline Observations & & 3 & 3 \\
\hline Pearson Correlation & & 0,928571429 & \\
\hline Hypothesized Mean D & nce & 0 & \\
\hline$d f$ & & 2 & \\
\hline t Stat & & 2,218800785 & \\
\hline$P(T<=t)$ one-tail & & 0,078362979 & \\
\hline t Critical one-tail & & 2,91998558 & \\
\hline$P(T<=t)$ two-tail & & 0,156725957 & \\
\hline t Critical two-tail & & 4,30265273 & \\
\hline
\end{tabular}

T hitung $<\mathrm{t}$ tabe

Kesimpulan : Ketangguhan memenuhi syarat

Ketangguhan dapat diuji untuk mengetahui adanya kesalahan nonlinier dengan cara uji $t$ student (Burns et al., 2009). Berdasarkan uji ketangguhan dapat dinyatakan bahwa ketangguhan metode analisis $\mathrm{Cd}$ memenuhi persyaratan, ditunjukkan dengan t-hit < t-tab (Tabel 7).

\section{KESIMPULAN}

Berdasarkan hasil studi, metode yang dikembangkan oleh laboratorium telah memenuhi kesesuaian metode Flame Atomic Adsorption Spectrofotometry, yang ditunjukkan dengan adanya kurva kalibrasi logam Cd yang linear, uji presisi dengan nilai lebih kecil dari nilai Horwitz, dengan persentase recovery antara 90$110 \%$. Perhitungan limit MDL sebesar 0,003 $\mathrm{mg} / \mathrm{L}$. Pengembangan metode yang dilakukan telah termasuk dalam kriteria selektif terhadap logam Cd. Pengembangan metode uji Cd juga dinilai telah memenuhi ketahanan dan ketangguhan. Hasil penelitian ini dapat direkomendasikan ke Badan Standardisasi Nasional untuk dikaji ulang mengenai pengukuran $\mathrm{Cd}$ air permukaan pada konsentrasi rendah.

\section{UCAPAN TERIMA KASIH}

Penulis mengucapkan terima kasih kepada Bapak Kepala Balai Riset dan Standardisasi Industri Banjarbaru yang telah memfasilitasi sarana dan prasarana serta semua pihak yang mendukung terlaksananya studi ini.

\section{DAFTAR PUSTAKA}

Ahmad, M. ., Islam, S., Rahman, M., Haque, M. ., \& Islam, M. . (2010). Heavy metals in water, sediment and some fishes of Buringanga River, Bangladesh. International Journal Environmental Research, 4(2), 321-332.

Araujo, P. (2009). Key aspects of analytical method validation and linearity evaluation. Journal of Chromatography B, 877(23), 2224-2234.

https://doi.org/10.1016/j.jchromb.2008.09. 030

Arefin, T. M., Rahman, M. M., U-Zzaman, M. W., \& Kim, J.-E. (2016). Heavy metal contamination in surface water used for irrigation: functional assessment of the Turag River in Bangladesh. Journal of Applied Biological Chemistry, 59(1), 8390. https://doi.org/10.3839/jabc.2016.015

Badan Standarisasi Nasional. (2009). SNI 066989.16-2009. Air dan air limbah - Bagian 
16: Cara uji kadmium (Cd) dengan Spektrofotometri Serapan Atom (SSA)nyala. BSN.

Burns, D. T., Danzer, K., \& Townshend, A. (2009). A tutorial discussion of the use of the terms "robust" and "rugged"and the associated characteristics of "Robustness"and "Ruggedness"as used in descriptions of analytical procedures. Journal of the Association of Public Analyst, 37, 40-60.

Censi, P., Spoto, S. E., Saiano, F., Sprovieri, M., Mazzola, S., Nardone, G., Di Geronimo, S. I., Punturo, R., \& Ottonello, D. (2006). Heavy metals in coastal water systems. A case study from the northwestern Gulf of Thailand. Chemosphere, 64(7), 11671176.

https://doi.org/10.1016/j.chemosphere.200 5.11 .008

Chan, C. C., Lam, H., Lee, Y. C., \& Zang, X.-M. (2004). Analytical method validation and instrument performance verification. John Wiley \& Sons, Inc. https://doi.org/10.1002/0471463728

Hadi, A. (2010). Penentuan batas deteksi metode (Method Detection Level) dan batas kuantifikasi (Limit of Quantitation) pengujian sulfida dalam air dan air limbah dengan biru metilen secara spektrofotometri. Ecolab, 4(2), 55-96. https://doi.org/10.20886/jklh.2010.4.2.7080

Harmita. (2004). Petunjuk pelaksanaan validasi metode dan cara perhitungannya. Majalah IImu Kefarmasian, 1(3), 117-135.

Horwitz, W., \& Albert, R. (1995). Precision in analytical measurements: Expected values and consequences in geochemical analyses. Fresenius' Journal of Analytical Chemistry, 351(6), 507-513. https://doi.org/10.1007/BF00322724

Iskandar, B., Panggabean, A. S., \& Kartika, R. (2017). Validasi metode penentuan arsenik pada sampe air sumur bor dengan menggunakan spektrofotometer serapan atom di PT. Geoservices Balikpapan. Jurnal Kimia FMIPA UNMUL, 34-39.

Islam, M. S., Han, S., Ahmed, M. K., \& Masunaga, S. (2014). Assessment of trace metal contamination in water and sediment of some rivers in Bangladesh. Journal of Water and Environment Technology, 12(2), 109-121. https://doi.org/10.2965/jwet.2014.109

Pemerintah Provinsi Kalimantan Selatan. (2007).
Peraturan Gubernur Kalimantan Selatan Nomor 05 Tahun 2007 tentang Peruntukan dan Baku Mutu Air Sungai. Pemerintah Provinsi Kalimantan Selatan.

Pourret, O., \& Hursthouse, A. (2019). It's time to replace the term "heavy metals" with "potentially toxic elements" when reporting environmental research. International Journal of Environmental Research and Public Health, 16(22). https://doi.org/10.3390/ijerph16224446

Pratama, D. S., Hidayat, D., Wijianto, E., \& Yuniar, H. (2016). Validasi metode analisis $\mathrm{Pb}$ dengan menggunakan Flame Spektrofotometer Serapan Atom (SSA) untuk studibiogeokimia dan toksisitas logam timbal pada tanaman tomat (Lycopersicum Esculentum). Analit: Analytical and Evironmental Chemsitry, 1(01), 26-35.

Purwanto, A., Supriyanto, C., \& Samin, P. (2007). Validasi pengujian $\mathrm{Cr}$, Cu dan $\mathrm{Pb}$ dengan Metode spektrometri serapan atom. Prosiding PPI-PDIPTN, 151-158.

Ravisankar, P., Naga Navya, C., Pravallika, D., \& Sri, D. N. (2015). A review on step-by-step analytical method validation. IOSR Journal Of Pharmacy, 5(10), 07-19.

Republik Indonesia. (2001). Peraturan Pemerintah Republic Indonesia Nomor 82 Tahun 2001 Tentang Pengelolaan Kualitas Air dan Pengendalian Pencemaran. Kementerian Lingkungan Hidup.

Roza, S. Y., \& Muhelni, L. (2019). Analisis Kandungan $\mathrm{Cd}, \mathrm{Cu}$ dan $\mathrm{Pb}$ pada air permukaan dan sedimen permukaan di muara-muara sungai kota Padang. Jurnal Akuatika Indonesia, 4(1), 1-5. https://doi.org/10.24198/jaki.v4i1.18915

Shah, A. B., Singh, R. P., \& Rai, U. N. (2020). Trends in phytomanagement of aquatic ecosystems and evaluation of factors affecting removal of inorganic pollutants from water bodies. Fresh Water Pollution Dynamics and Remediation, 247-262. https://doi.org/10.1007/978-981-13-82772_14

Soliman, N. F., Younis, A. M., \& Elkady, E. M. (2019). An insight into fractionation, toxicity, mobility and source apportionment of metals in sediments from El Temsah Lake, Suez Canal. Chemosphere, 222, 165-174.

https://doi.org/10.1016/j.chemosphere.201 9.01 .009

Sukaryono, I. D., Hadinoto, S., \& Fasa, L. R. 
(2017). Verifikasi metode pengujian cemaran logam pada air minum dalam kemasan (AMDK) dengan metode AASGFA. Majalah Biam Kementerian Perindustrian Republik Indonesia, 8-16. http://ejournal.kemenperin.go.id/bpbiam/ar ticle/download/1965/pdf_19

Sumardi. (2002). Validasi metode pengujian.

Tjahjono, A., \& Suwarno, D. (2018). The spatial distribution of heavy metal lead and cadmium pollution and coliform abundance of waters and surface sediment in demak. Journal of Ecological Engineering, 19(4), 43-54. https://doi.org/10.12911/22998993/89715

US Environmental Protection Agency. (2016). Definition and procedure for the determination of the method detection limit-Revision 2. In Epa 821-R-16-006 (Issue December, pp. 1-8). https://www.law.cornell.edu/cfr/text/40/part -136/appendix-
B\%5Cnhttp://www.epa.gov/region9/qa/pdf s/40cfr136_03.pdf

Yang, K., Zhu, L., Zhao, Y., Wei, Z., Chen, X., Yao, C., Meng, Q., \& Zhao, R. (2019). A novel method for removing heavy metals from composting system: The combination of functional bacteria and adsorbent materials. Bioresource Technology, 293, 122095.

https://doi.org/10.1016/j.biortech.2019.122 095

Yi, Y., Yang, Z., \& Zhang, S. (2011). Ecological risk assessment of heavy metals in sediment and human health risk assessment of heavy metals in fishes in the middle and lower reaches of the Yangtze River basin. Environmental Pollution, 159(10), 2575-2585. https://doi.org/10.1016/j.envpol.2011.06.01 1 